of Mucor and the blue-green mould Penicilium were also examined using the same solution for impregnation, and black granules were found in the mycelium and in the spores. The protoplasm in various types of Algæ, for example, Spirogyra (Chlorophyceæ) and Oscillatoria (Cyanophyceæ) was seen to contain varying numbers of fine granules. In Oscillatoria at the growing tip the granules were orientated in lines radiating backwards from the tip. The granules in the segments farther back were scattered irregularly in the centre of the segment. In specimens of lichen examined, the algal cells contained only a few granules, but the fungal element of the lichen possessed a greater number of granules, aggregated chiefly in the centre of the hyphæ.

It is apparent, then, that in these lower forms of life there is a substance capable of reducing a reagent which in higher forms of life is specific for vitamin C. It is suggested, therefore, that this reducing substance in these lower organisms is vitamin $\mathrm{C}$, in which case it may be that the very existence of living proto. plasm is dependent upon the presence of this vitamin. It has been shown in Eutherian mammals, and more recently in the marsupials also, that vitamin $\mathrm{C}$ occurs in all the organs of the body, although varying considerably in concentration in the different tissues. It is present in high concentration in the pituitary and adrenal glands, the corpus luteum and interstitial gonadial cells, and, to a lesser extent, in the liver. It is also present in the adreno-cortical homologues of certain fishes.

The suggestion is that vitamin $\mathrm{C}$ is essential for the existence of living protoplasm, probably as an integral part of an oxidation reduction system. Its high concentration within certain organs may indicate a non-specific catalysis of the manufacture of the hormones of those organs.

Geoffrey Bourne. Russell Allen.

Department of Experimental Biology and Physiology,

Australian Institute of Ánatomy, Canberra, F.C.T.

\section{Plural Nature of Vitamin B}

ONE group of rats was supplied with vitamin B carriers that had been subjected to intense ultra. violet irradiation. The animals developed a severe dermatitis and died. A second group received tikitiki, an alcoholic extract of rice polishings, as the sole source of vitamin B. After some ten or twelve weeks these rats became denuded, assumed a very miserable appearance, and finally they died also.

Wheat germ oil and flavines have unique properties in treating these abnormalities. The denuded condition is healed by either hepatoflavine or lactoflavine, and the rats grow rapidly on the combination of tikitiki and flavine. Wheat germ oil is ineffective. The dermatitis is not relieved by flavines, but is healed by wheat germ oil. Growth will not be sustained unless the irradiated supplement is fortified both by wheat germ oil and flavines. Ultra-violet irradiation destroys two vitamins. One is flavine, the other is the unidentified factor required to prevent dermatitis. Albert G. Hogan. Luther R. RiohaRdson.

Missouri College of Agriculture, Columbia, Missouri. June 21.

\section{Rarity of the Archaic Arachnids, Podogona (Ricinulei)}

The writer of the review in Nature of June 29 of Mr. Savory's book on Arachnida refers to a statement made by that author with regard to the number of specimens of Podogona or Ricinulei known to exist. The number of specimens representing the thirteen living species of Podogona was estimated at thirty. two.

This figure was correct when Kästner wrote his monograph on the group in Kükenthal and Krumbach's "Handbuch der Zoologie" (1932), but in the summer of the year 1933, Mr. Ivan T. Sanderson presented a collection of no less than three hundred and seventeen specimens of Cryptostemma sjöstedti to the British Museum (Natural History). These Podogona were collected by Mr. Sanderson on the Percy Sladen Trust Expedition to Nigeria and the British Cameroons, 1933. Only seventeen specimens were adult, the rest being nymphs except for one six-legged larval form. Mr. Sanderson also managed to bring back twenty living specimens, which were kept alive for twelve months in an incubator in the Museum. During this time they were exhibited at the Royal Society soirée in June 1934 and at the Linnean Society, and Mr. Sanderson had a very interesting film made showing their curious gait, and the cataleptic state induced by sudden intense light or slight movement.

The acquisition of this valuable collection and the light it has helped to throw on this obscure group tempt one to quote further from Mr. Savory's book and say it ". . . is a challenge to those collectors fortunate enough to find themselves in the right neighbourhood".

Department of Zoology,

Susan Finnegan.

British Museum (Natural History).

\section{Surface Tension of Heavy Water}

Selwoon and Frost ${ }^{1}$ obtained for mixtures of varying proportions of ordinary and heavy water different values of surface tension, the surface tension becoming smaller as the $\mathrm{D}_{2} \mathrm{O}$ concentration increased. These authors compute by extrapolation that pure heavy water has a surface tension of $67 \cdot 8 \mathrm{dyn} . / \mathrm{cm}$. at $20^{\circ} \mathrm{C}$. No other data can be found in literature, especially no direct measurements of surface tension of pure heavy water.

When dealing with another problem, there arose a necessity of carrying out such a measurement with 99.2 per cent $\mathrm{D}_{3} \mathrm{O}$ obtained from the Norsk Hydro. elektrisk Kvaelstofaktiebolaget, of Oslo, Norway.

\begin{tabular}{|c|c|c|c|c|}
\hline $\begin{array}{c}\text { Radius of the } \\
\text { capillary } \\
\text { bore } \\
\text { (cm.) }\end{array}$ & $\begin{array}{c}\text { Surface tension } \\
\text { or ordinary } \\
\text { water } \\
\text { (dyne/cm.) }\end{array}$ & \multicolumn{3}{|c|}{$\begin{array}{c}\text { Surface tension of } \\
\text { heavy water in dyne/cm. }\end{array}$} \\
\cline { 3 - 5 } & $\begin{array}{c}\text { I } \\
d=1 \cdot 1053\end{array}$ & $\begin{array}{c}\text { II } \\
d=1 \cdot 1048\end{array}$ & $\begin{array}{c}\text { III } \\
d=1 \cdot 1049\end{array}$ \\
\hline 0.013526 & $73 \cdot 0$ & $72 \cdot 7$ & $72 \cdot 6$ & $72 \cdot 6$ \\
0.019503 & $72 \cdot 0$ & $72 \cdot 1$ & $71 \cdot 5$ & $71 \cdot 2$ \\
0.025364 & $72 \cdot 4$ & - & $71 \cdot 8$ & 72.0 \\
\hline
\end{tabular}

Preliminary experiments carried out by means of the du Noüy precision tensiometer gave for this water a surface tension value of $72 \cdot 6 \pm 1 \mathrm{dyne} / \mathrm{cm}$., the corresponding value for ordinary water being $72 \cdot 8$ dyne/cm. More accurate measurements were made by the ascension method at $20^{\circ} \mathrm{C}$., all usual 